\title{
A Research on Book Reading Habits of Turkish Teachers
}

\author{
Ahmet Akçay \\ Correspondence: Ahmet Akçay, Department of Turkish and Social Sciences Education, Education Faculty, Ağrı \\ İbrahim Çeçen University, Ağrı, Turkey.
}

Received: August 20, 2017

doi:10.11114/jets.v5i10.2609

\author{
Accepted: August 28, 2017 \\ Online Published: September 6, 2017
}

URL: https://doi.org/10.11114/jets.v5i10.2609

\begin{abstract}
Reading is the act of understanding and interpreting itself and its surroundings from the moment that human being is present. Therefore, individuals those who would like to know the environment better should have gained the reading habit. Turkish teachers are one of the effective factors in the acquisition of reading habits. It is necessary for the Turkish teachers who are role-models in every sense to be an example in reading books and encourage them. The purpose of this research is to examine the reading habits of Turkish teachers. In the study, the screening model was pursued with purpose of the determine the reading habits of Turkish teachers. As for that the sample of the research, is consist of 92 Turkish Teachers. By using easily accessible sampling method in the study, the teachers, who are on duty in these two countries, have been involved in the study. In order to collect data in the study, "Personal Information Form", where 4 questions about teachers 'personal information were prepared, and prepared "Reading Habit Form", which was used to describe teachers' reading habits, were being used. As a result of the study, it has been determined that Turkish teachers read regular books, have limited time to read daily books, prefer literary works to read frequently, do not follow any newspaper or magazine, and can not allocate the necessary budget for the book.
\end{abstract}

Keywords: book, reading, reading habit, Turkish teacher

\section{Introduction}

Reading is the act of understanding and interpreting itself and its surroundings from the moment that human being is present. Reading is the process of giving meaning to objects and situations that are not only meaningless but also visually perceived by some existing writing units. Many situations such as knowledge, thoughts, feelings, dreams, etc. have been become reality by the act of reading (Edizer, 2014).

Manguel (2007: 19) defines reading as "to read the written characters on a page is only one of the forms of reading. A zoologist who reads animal traces in the forest, the weaver who reads the complex pattern of the woven garment, the artist who reads the index of multiple notes combined on the page. They all perform the action of decoding and making the signals clear" (as cited in Koçak et.al, 2016). Akay (2009) refers to this wide range of reading and deep structure as "reading is one of the most serious jobs in the world (and perhaps the first of the most serious jobs when it is considered in philosophical context)". Güneş (2003) describe that read, as a sum of skills not a skill; while the Yalçın (2006:47) defines individual symbols that individuals understand on their interpretation through the senses in the brain; as for that Akyol (2006:29) defines the reading as a process of establishing a dynamic meaning that requires active and effective communication between writer and reader.

Individuals apply the most practical and quickest way of reading in the process of obtaining information. Individual is updating itself by continuing the reading process and progressing towards becoming universal beyond the boundaries of the existing information world (Ungan, 2008). One of the most basic features that distinguish human beings from other living things is to provide the continuation of this knowledge and to transmit it to future generations. Rapid proliferation of transferred information makes indispensable by increasing the importance of reading (Konan, 2013:32). For this reason, individuals who do not read in the age of change and in the world, are losing their speed and having difficulty finding out how to read and what to read / learn.

The reading activity is not only an individual activity but also a social activity (Balc1, 2013: 11). "The purpose of creating a functional readership is to create a society that enlightens the human power of the country and demands the right to be independent, upright, productive and producing" (Sarıhan, 2003: 31). This is because reading is not only confined to the areas where education is made but is actively used in all areas of life until the end of life. The fact that reading has such a common daily life, has a direct impact on social development. As a matter of fact, Reading rates and development levels 
of countries and developed societies show that parallelism. As the storage and sharing of information becomes possible with reading grows, creative ideas become even easier to come up with.

Knowledge is learned through senses and experiences. The learned and acquired knowledge can become a skill but only with a habit (Kırkkılıç and Maden, 2009). This is because the most effective and lasting method in the continuous transformation of the reading process is to gain reading habits. Even as Konan (2013), defines reading habits as the continuation and criticism of the individual as he progresses through the reading process he or she has learned and throughout life, as for that Özçelebi and Cebecioğlu (1990) defines the reading habit as "perceiving it as a necessity and pleasure source, to realize the end result reading in a continuous, regular and critical way". Reading habit can be described as the conversion of the reading action into an action by internalizing it with the most general definition.

There are some criteria in the conversion of reading to habit. Dökmen (1994:34) ranked some of these criteria as what kind of publications did the reader read, how often and which types, what they read, how long it can be read uninterrupted at one time; which time that they preferred to read the year, week or day; (buy, borrow, or in the library reading ways, which one or which they prefer) how to provide books when and where they read and feel pleasure.

Reading habits have individual and social influences. One of these effects is the significant difference in the individuals. Individuals who make a difference are those who devote time to reading, and who transmit their life stories in the meantime. The main factor in the formation of this difference is the reading habit existing in the individual (Konan, 2013). Because individuals who acquire reading habits perceive reading as a necessity, they continue to read books throughout life (Şahin, 2009). This, creates a society that acquires the habit of reading books in tow. A society with a reading habit and the level of this habit in that society also shows the level of community development (Arslan, Orhan and Akçay, 2011). This is because that there is a significant correlation among the reading rates of developed societies and the level of prosperity.

Individuals have an important role to play in the environment as well as during individual development periods when they are interested in reading and acquiring habits. In the immediate vicinity, family, friends and teachers are highly influential on the individual's own reading discipline (Y1lmaz, 2014: 16). In particular, the teachers are effective in ensuring the continuation of reading habits (Yağc1, 2007: 66). Trainee (s) / teachers need to have a specific reading culture and habit of educators / teachers first of all in propose appropriate books to students, motivate students to read books and turn them into a habit by making it permanent (Bozpolat, 2010). Because the teachers, who are the architects of the education and training institutions that target the nationality of the societies and the cultivation of the societies, has a very important influence on the environment, especially the students.

There have been many researches on reading habits, reading interest and attitudes among teacher and teacher candidates in body of literature. In study conducted by Gömleksiz and Telo (2003) on teacher candidates of Firat University Faculty of Education, it has been determined that teacher candidates do not acquire reading culture and reading habits. In this case, the fact that they are far from being directed by a mass of conscious readers is effective.

In the study conducted by Gömleksiz (2004) at Firat University, a total of 350 teachers, of whom 163 male and 187 female, tried to determine the reading habits, attitudes and opinions of the candidates. As a result of the study, it was determined that the reading habits and reading cultures of female teacher candidates are more, the necessity of reading a book and its benefits are more important to female teacher candidates than to female teacher candidates.

In the study conducted by Sağlam, Suna and Çengelci (2007) at Anadolu University Faculty of Education have found that the reading habits of the teacher candidates reading in the classroom teacher section are at a moderate level.

In the study conducted by Özbay, Bağcı and Uyar (2008) among 320 Turkish teacher candidates at Gazi University, have determined that the attitudes of the Turkish teacher candidates regarding their reading habits regarding love, habit, necessity and desire sub-dimension are found to be significantly different in female students according to male students and that those who follow the periodicals in Turkish teacher candidates are more positive in their attitudes towards these variables. In addition, it has been determined that the attitudes of the teacher candidates to the sub-dimensions of reading habits make a meaningful difference according to the book reading frequency of the teacher candidates.

Aslantürk (2008) compared reading interests and habits among classroom teacher candidates and classroom teachers in his work "comparisons of reading interests and habits of class teachers and class teacher candidates" and, has determined that the number of classroom teacher candidates is higher than that of class teachers.

In the study conducted by Odabaş, Odabaş and Polat (2008) at Ankara University, have obtained that there is no reading consciousness in most of the students and female students had more reading cultures than male students.

In the study pursued by Geçgel and Burgul (2009) among 438 teachers candidates at Çanakkale Onsekiz Mart University Faculty of Education, stated that the majority of teacher candidates read one book a month and half of these candidates do not follow any periodical publication. Furthermore, it has been determined that a large majority of teacher candidates do 
not have enough time to read and the reason is observed that "the courses are very busy and you can not find time to read", "can not turn reading into a habit" and "preparing for KPSS exam".

In the study pursued by Demir (2009) among 261 teachers candidates at Gazi University Faculty of Education, has studied the reading habits and attitudes of teacher candidates according to different variables such as gender, graduated high school type, department, type of education and education status of father and mother. It has been found out that attitudes such as liking to read books, having a habit of reading books, necessity, willingness, influence and benefit are more meaningful and positive in female teacher candidates than male students. In addition, a significant difference has also been made regarding the sections read by teacher candidates. No significant difference was determined with respect to the graduated high school, the type of teaching, the educational status of the father, the educational status of the mother.

Batur, Gülveren, Bek (2010) 's attitudes towards reading habits of 420 teacher candidates at Usak University and the factors affecting these attitudes were investigated, it has been determined that female teacher candidates have more favorable holding than male teacher candidates. It also resulted in positive attitudes towards reading between departments and classes.

In the study pursued by Arı and Demir (2013) among 278 teachers candidates at Çanakkale Onsekiz Mart University Faculty of Education, have found that approximately 58.3\% of the teacher candidates read an average of 0-7 books per year. In the reading attitude, female teacher candidates were found to make a meaningful difference compared to male teacher candidates. The reading attitude of the variables such as section, education status, education level of parents, place of residence and average monthly income of the family, has come to the conclusion that no meaningful difference has occurred.

In the study pursued by Yalman, Özkan, Başaran (2015) among 200 teachers candidates at Çanakkale Dicle University, has been determined that the teacher candidates will contribute to cultural accumulation by having a book reading consciousness, that their self-esteem will increase and that they will be regarded as being valued in society. It has been determined that the individual who believes that the teacher candidates will contribute the most to the book cultures is the individual and his / her friends. As for that the interruption of reading habit, internet, social media, technological tools, as well as factors that are effective in examinations have been determined.

In order to determine the teachers' confrontation with the reading, according to a research result; it has been determined that 15 of the 675 teachers who took part in the research for a period of five years read more books than 10 books and the remaining 660 teachers below 10 books per year and 510 of the teachers did not read books at all (Soysal, 1988).

Studies performed show that the reading habits of the teacher and the teacher candidates and the reading ratios are low, and the variables such as gender, age, education status affect the reading interest and attitudes. It was determined that teachers' reading attitudes are influential on students and reading cultures affect students. In the light of the information listed abovementioned, this study, was performed for the purpose of examining the reading habits of Turkish teachers that students are expected to be an example in reading books as well as being in the majority, and they have a big share in bringing language skills to students.

\section{Method}

\subsection{Research Model}

In the study, the Screening model was pursued with purpose of the determine the reading habits of Turkish teachers. Screening models is a research approach aimed at describing the past or present as it exists. The event that is the subject of the investigation is tried to be defined as if the individual or object is within its own conditions (Karasar, 2000). In this study, it is aimed to describe the situations in which Turkish teachers read books.

\subsection{Universe and Sampling}

The universe of the study is composed of Turkish teachers working between 2015-2016 who are working in Ağr1 and Erzurum province. The sample of the study is composed of 92 Turkish teachers who are working in these two countries. By using easily accessible sampling method in the study, the teachers, who are on duty in these two countries, have been involved in the study. The information related to the Turkish teachers who make up the sample is depicted in Table 1 . 
Table 1. Information on Teachers in the Research

\begin{tabular}{lcc}
\hline Gender & F & \% \\
\cline { 2 - 3 } Male & 47 & 51 \\
Age & 45 & 49 \\
\hline $22-25$ & 45 & 49 \\
$26-29$ & 31 & 34 \\
$30-33$ & 11 & 12 \\
$34-37$ & 5 & 5 \\
Type of School Graduated & 82 & 89 \\
\hline Faculty of Education & 10 & 11 \\
Faculty of Arts and Sciences & & 85 \\
Service Year & 78 & 11 \\
\hline 0-5 years & 10 \\
6-10 years & 4 & 4 \\
\hline
\end{tabular}

\subsection{Data Collection and Analysis}

In order to collect data in the study, "Personal Information Form", where 4 questions about teachers 'personal information were prepared, and prepared "Reading Habit Form", which was used to describe teachers' reading habits, were being used. The form prepared by the researchers is finalized in consequence of the opinions of two persons who are experts in the field of Assessment and evaluation other than Turkish teaching. Descriptive statistical descriptors such as frequency and percentage have been used in the analysis of the data.

\section{Results}

The results obtained in the study are depicted in the following headings.

\subsection{Results Related to the Regular Reading of Turkish Teachers}

The first question in the "Reading Habit Form" is about whether Turkish teachers read regular books. 65\% of Turkish teachers answered this question in the form of reading books on a regular basis. As shown in Table 2, 35\% of the teachers do not define themselves as regular readers.

Table 2. Turkish Teachers' Regular Reading Status

\begin{tabular}{lcc}
\hline Regular Reader & F & $\%$ \\
Yes & 60 & 65 \\
No & 32 & 35 \\
\hline
\end{tabular}

\subsection{Results Regarding the Time Those Turkish Teachers Have Reserved to Read Books outside the Course}

Turkish teachers often read in their lessons. Especially during the reading period of free books, most teachers are reading books which will be an example for the students. Results related to the length of time that Turkish teachers spend reading a book every day outside of their class time are depicted in Table 3. According to this, $30 \%$ of Turkish teachers spend time reading books between 10 and 30 minutes during the day. The rate of teachers who read books over 120 minutes is $9 \%$.

Table 3. Reading Times of Turkish Teachers Outside of the Course

\begin{tabular}{lccc}
\hline The Time Allocated To Reading Outside The Course & F & $\%$ \\
10-30 min. & 28 & 30 \\
31-60 min. & 21 & 23 \\
61-90 min. & 19 & 21 \\
91-120 min. & 16 & 17 \\
120 min. and over & 8 & 9 \\
\hline
\end{tabular}

\subsection{Results Related to the Number of Books Read by Turkish Teachers in 1 Year}

Results related to the number of books read by Turkish teachers who participated in the study in 1 year are depicted in Table 4. According to this, $30 \%$ of the teachers stated that they read at least 21 books in 1 year. In addition, there are no teachers in the study who do not read books. 
Table 4. Number of Reading Books of Turkish Teachers Outside of the Course

\begin{tabular}{lcc}
\hline Number of Books Read in 1 Year & F & \% \\
None & 0 & 0 \\
$1-5$ & 10 & 11 \\
$6-10$ & 22 & 24 \\
$11-15$ & 14 & 15 \\
$16-20$ & 18 & 20 \\
21 and over & 28 & 30
\end{tabular}

\subsection{Results Related to the Types of Books That Turkish Teachers Often Read}

It is understood from Table 5 that novels (25\%) are among the most frequently read works of Turkish teachers. The books most frequently read by teachers after the novels are poetry (12\%), personal development $(11 \%)$ and story (10\%).

Table 5. The Types of Books that Turkish Teachers Often Read

\begin{tabular}{lcc}
\hline Book Types & $\mathrm{F}$ & $\mathbf{\%}$ \\
Novel & 23 & 25 \\
Poem & 11 & 12 \\
Personal development & 10 & 11 \\
Story & 9 & 10 \\
Humor & 8 & 9 \\
Philosophy & 6 & 7 \\
Art & 6 & 7 \\
Politics & 5 & 5 \\
Professional development-Academic & 5 & 5 \\
Religion & 4 & 4 \\
History & 4 & 4 \\
Technology & 1 & 1 \\
\hline
\end{tabular}

\subsection{Results Related to the Numbers of the Books in the Bookcase of Turkish Teachers}

The question related to numbers of the books in personal libraries directed to Turkish teachers, $38 \%$ of the teachers answered that they had 151 books in their library. According to Table 6,7\% of the teachers in the study stated that they had between $0-25$ teachers.

Table 6. Number of Books in Bookshelves of Turkish Teachers

\begin{tabular}{lcc}
\hline Number of Books & F & $\%$ \\
$0-25$ & 6 & 7 \\
$26-50$ & 9 & 10 \\
$51-100$ & 19 & 20 \\
$101-150$ & 23 & 25 \\
151 and over & 35 & 38 \\
\hline
\end{tabular}

\subsection{Results Related to Turkish Teacher Temporary Newspaper/Magazine Follow up Situations}

Related to the Periodical magazine / newspaper follow up situations reached the conclusion that $75 \%$ of Turkish teachers did not follow any newspaper or magazine and $25 \%$ followed a magazine or newspaper.

Table 7. Turkish Teachers Temporary Newspaper/Magazine Follow up Situations

\begin{tabular}{lcc}
\hline Newspaper / Magazine Follow-up & F & \% \\
Yes & 23 & 25 \\
No & 69 & 75 \\
\hline
\end{tabular}

3.7 Results Related to Turkish Teachers Temporary Newspaper / Magazine Follow up Period Situations

The 23 teachers participated in the study stated that they had followed a periodical newspaper or magazine. While $70 \%$ of these teacher candidates indicated that the periodical publication they were following was daily, $22 \%$ reported that they were following a periodical publication on a monthly basis. 
Table 8. Turkish teachers temporary Newspaper / Magazine follow up Periods

\begin{tabular}{lcc}
\hline Newspaper / Magazine Follow-up & F & $\%$ \\
Daily & 16 & 70 \\
Weekly & 1 & 4 \\
Monthly & 5 & 22 \\
3-6 months & 1 & 4 \\
Yearly & 0 & 0 \\
\hline
\end{tabular}

\subsection{Results Related to the Budget of Turkish Teachers for Books}

Results related to the budget of Turkish teachers monthly for the book are depicted in Table 9. The vast majority of teachers stated that they could allocate few budget to books. The rate of teachers who can budget between 0-50 TL for books is $53 \%$ and the rate of teachers who have indicated that budget between $51-100$ TL is $35 \%$.

Table 9. The Budget of Turkish Teachers for Books

\begin{tabular}{lcc}
\hline Budget & F & $\%$ \\
$0-50 \mathrm{TL}$ & 49 & 53 \\
$51-100 \mathrm{TL}$ & 32 & 35 \\
$101-150 \mathrm{TL}$ & 7 & 8 \\
$151-200 \mathrm{TL}$ & 3 & 3 \\
$201-250 \mathrm{TL}$ & 1 & 1 \\
250 TL and over & 0 & 0 \\
\hline
\end{tabular}

3.9 Results Related to Preferences of Turkish Teachers to Read Books

Turkish teachers mostly prefer to read books in print. According to Table 10, the rate of teachers reading books both in print and online is about $10 \%$.

Table 10. Preferences of Turkish Teachers to Reading Books

\begin{tabular}{lcc}
\hline Preferences & F & $\%$ \\
Printed & 67 & 73 \\
Online & 16 & 17 \\
Printed + Online (online) & 9 & 10 \\
\hline
\end{tabular}

\subsection{Results Related to Reading Tools of Turkish Teachers Who Preferred Online}

16 teachers who preferred online were asked to reading tools and it is determined that the book makes use of four different tools in reading. While teachers often state that they use tablet computers for reading books mostly, apart from this, they also stated that they use laptop computers (25\%), mobile phones (12\%) and e-book readers (6\%) as shown in Table 11.

Table 11. Reading Tools of Turkish Teachers Who Preferred Online

\begin{tabular}{llc}
\hline Tools & F & $\%$ \\
Mobile phone & 2 & 12 \\
Tablet computer & 9 & 56 \\
Laptop-desktop computer & 4 & 25 \\
E-book reader & 1 & 6 \\
\hline
\end{tabular}

\subsection{Results Related to Reading Book Priorities of Turkish Teachers}

Results related to reading book priorities of Turkish teachers are depicted in Table 12. Accordingly, teachers mostly read books in order to acquire general culture. $28 \%$ of teachers read books with purpose of professional development. Moreover, according to the statements of the Turkish teachers in the research, the rate of reading books is low on the purpose of spending time. 
Table 12. Priorities of Turkish Teachers to Read Books

\begin{tabular}{lcc}
\hline Priority & F & $\%$ \\
Spending time & 10 & 11 \\
Vocational development & 26 & 28 \\
Personal development & 12 & 13 \\
Acquisition of general knowledge & 33 & 36 \\
Follow-up the agenda & 11 & 12 \\
\hline
\end{tabular}

\section{12 Results Related to the Average Reading of the Works in 100 Basic Works of Turkish Teachers}

Results regarding the readings of the books in 100 Basic Works, which are recommended by secondary school students and read by the Turkish teachers, are shown in Table 13. Accordingly, the ratio of teachers who read all of the 100 Basic Works is approximately $17 \%$.

Table 13. Average Reading Situations of 100 Basic Works of Turkish Teachers

\begin{tabular}{lcc}
\hline Average Number of Read Books within 100 Basic Works & F & \% \\
$0-20$ & 14 & 15 \\
$21-40$ & 18 & 20 \\
$41-60$ & 32 & 35 \\
$61-80$ & 12 & 13 \\
$81-100$ & 16 & 17
\end{tabular}

\section{Discussion}

This study performed, was study that contributed to reveal the type of literacy of Turkish teachers. According to the definition made by the American Library Association, readers who read less than 5 books a year are less likely to read, 6-20 books per year read at medium level, and readers who read more than 20 books per year are considered as well-readers (Sağlamtunç, 1990; Yilmaz, 2004a). Among the Turkish teachers who participated in the study, the ratio of teachers who have many types of readers is around 30\%. This rate is very low for Turkish teachers.

While $65 \%$ of Turkish teachers regarded the book as regular readers, $35 \%$ do not define themselves as regular readers. Being a regular reader requires that acquiring reading habits. In this respect, Turkish teachers should start their duties by acquiring this habit.

The studies conducted on teacher candidates indicate that teacher candidates do not read books at an adequate level. (Olson and Gillis, 1983; McNinch and Steelman, 1990; LaBonty, 1991; Myers, 1993; Timbs, 1993; Esgin and Karadağ, 2000; Semerci, 2002; Balc1, 2003; Saracaloğlu, Bozkurt and Serin, 2003; Saracaloğlu, Karasakaloğlu and Yenice, 2007; Kolaç, 2007). According to Odabaş, Odabaş and Polat (2008) study, 4.6\% of the students never read books in a year, 46.1\% read between 1 and 5 books, while 38,5\% read books between 6-11, 10,9\% read more than 12 books. In the study of Kuş and Türkyılmaz (2010), it was determined that the frequency of reading of teacher candidates is low. On the other hand, studies that are seen to have positive reading habits of the students in the general sense are also included in the literature (Batur, Gülveren, and Bek 2010). When these studies are evaluated in general, it is obvious that it is necessary to give teacher candidates the habit of reading books before the service.

The results are not very different in the researches carried out on the teachers (Y1lmaz, 2004b; Atak et al., 2007). According to study by Yilmaz (2002), it has been determined that as the age increases and the professional experience increases, the reading habits of the teachers decrease, the teachers had a serious reading habit problem, levels of reading magazines were inadequate, and the habits of using the public library are little if any. In the study of Şahiner (2005), it has revealed that teachers were less able to use the school and public libraries and did not see themselves adequately in reading. In addition, the majority of the teachers in the survey stated that the reading period regarding the difference between university years and reading in the present period is decreasing. In the study conducted by Aslantürk and Saracaloglu (2010) it has been examined the interests and habits of reading both teachers and teacher candidate. As a result of the study, it was determined that the reading and the information of the teachers and the prospective teachers were moderate. In this study, it has been determined that $30 \%$ of Turkish teachers spend time reading books between 10 and 30 minutes a day during off-course hours and that the rate of teachers who read books over 120 minutes is $9 \%$. It can be stated that the studies listed above correspond to the results of this research.

In the Candidate Teacher Training Program prepared by the Ministry of National Education (2016) suggested 31 different 
books belonging to domestic and foreign authors to teacher candidates for reading purposes and is obligatory for reading 5 of the books. In addition, the Ministry of National Education has placed a form on its site for evaluating the books that the teachers candidate read. In order to examine the reading situations of the candidate teachers, according to the report titled "Teacher training model in Turkey - monitoring and evaluation" prepared by İlyas, Coşkun and Toklucu (2017), candidate teachers' reading rates of the books set by the Ministry of National Education are very low. According to the data obtained from 17 thousand 619 teacher candidates, teacher candidates' average reading the selected books ratio is 4,8 book. This average, which is determined to be quite low, is also below the number of books that the Ministry of Education wants to read. The reading habit behaves in a way that should be kept alive throughout life (Batur, Gulveren and Bek, 2010). Considering that reading a book is a habit, it is possible to say that the candidate teachers who are far away from the beginning of the professions will also be away from the future profession. Turkish teacher candidates should have been aware of the importance of reading books before serving and have made it a habit (Akin, 2015).

According to the conclusion of this study, the most frequently read works of Turkish teachers are novels, and novels are followed by poetry, personal development and story books. Teachers need to improve themselves in many fields. Teachers feel the need to read books in the 9 field (Yıldırım, 2013):

1. Books for understanding and defining student behaviors

2. Contact

3. Teaching methods

4. Classroom practices

5. Books oriented to Parents

6. Books related to the School

7. Contemporary education thematic books

8. Practical books specific to the field

9. Books about life

It is seen that Turkish teachers read more literary genres such as novels, poems and stories despite the fact that teachers feel the need to read in these areas. However, they also stated that read personal development books. This result is show parallelism with Şahiner's (2005) study. In Şahiner's (2005) study, the vast majority of teachers point out that they read newspapers and magazines besides literary genres, in this study it was reached that $75 \%$ of the Turkish teachers did not follow any newspaper or magazine, $25 \%$ of them follow a magazine or a newspaper. Furthermore, teachers mostly read books in order to acquire general culture. $28 \%$ of teachers read books with purpose of professional development. Moreover, according to the statements of the Turkish teachers in the research, the rate of reading books is low on the purpose of spending time. It is possible to say that most of the Turkish teachers do not follow the current and academic developments. Teachers were not sufficiently informed about the importance of reading habits in their undergraduate education and how they would be taught to students, did not use enough libraries during their undergraduate education, and they have started with deficient for these habits in the profession in terms of both consciousness and practice (Y1lmaz, 2002). This leads to the teachers' reading habits to be in this direction. In addition, literary texts frequently appear in the content of the Turkish course. It can be said that capture this content, recommend books for students to read, and become role models for students is effective when teachers mostly prefer literary genres. Nevertheless, it is very interesting that the teachers' recommended for secondary school students to read the 100 Essential Works in the desired works to read, rates remain around $17 \%$ in the study. However, it is necessary for the Turkish teachers to be in favor of the students primarily by reading these works, taking into account the examinations and student levels.

The main reasons why teachers do not read enough books is that the reading material is expensive and it is not possible to allocate the necessary budget for it (Yllmaz, 2002). The vast majority of Turkish teachers stated that they could allocate few budget to books. They stated that they can mostly allocate between 0-50 TL in the books. In addition, there are often 151 or more books in their bookcase. With reference to the study of Şahiner (2005), this ratio can be regarded as sufficient for Turkish teachers. But it is seen as a big problem to be able to allocate budget for the book in terms of teachers. The study conducted also confirms that teachers have experienced various problems in terms of salary. Teachers are not finding their salaries enough, stating that they could not earn the income they earned in return for their work, that their income is not sufficient for their livelihood and that they require pay an additional fee according to the working environment. Teacher salaries are below the OECD average (Tunçkaşık, 2007, Türk Eğitim Sen, 2011, Eğitim-Bir-Sen, 2013). The study of Süngü (2012) also shows that when teacher salaries are compared with other professions, are lower level. In the study of Sönmez (1989), suggests that the average monthly net wage paid to teachers is well below that required for human life. Of course, because this research was done many years ago, the current situation is thought to have improved compared to previous years. Notwithstanding, the initial salary of teachers in Turkey is still behind most OECD countries (Eğitim-Bir-Sen, 2016). Because of this, it can be considered that teachers could not allocate sufficient budget for the book. 


\section{Conclusion and Recommendations}

As a result of this study in which the reading habits of Turkish teachers are examined, has been reached that the fact that Turkish teachers read regular books, daily reading time is limited, they prefer literary works to read frequently, that they did not follow any newspaper or magazine, can not allocate the necessary budget for the book, that reading priorities are more about acquiring general culture. It is necessary for the Turkish teachers who are role-models in every sense to be an example in reading books and encourage them. For this to happen, teachers need to start by gaining to the habit of reading books. As a result of this study, the following suggestions are possible:

1. Before the service, various activities should be organized in order to gain the reading habit of teacher candidate and teachers should start with a habit of acquiring this habit.

2. Teachers who have been successful in reading and developing competitiveness in reading should be given various awards.

3. In order for teachers to follow newspapers and magazines, teachers should be provided with access to them in schools by subscribing to certain journals.

4. By understanding with the publishing houses, teachers should be allowed to book cheaper on behalf of teachers.

5. In order to allocate teachers especially to book purchases, this budget should be used only for this.

6. The school libraries should be enriched and the number of books in the library should be increased with the books of various types by taking the opinions of the teachers in the book purchase process.

\section{References}

Akay, H. (2009). A new aspect to 'reading': reading by taking notice of what is meant -reading through different aspects. Turkish Studies, 4(3), 21-41. https://doi.org/10.7827/TurkishStudies.671

Akın, E. (2015). Turkish teacher candidates' reading habit analysis from various attitudes towards (siirt university example). Journal of Research in Education and Teaching, 4(4), 364-373.

Akyol, H. (2006). Turkish teaching methods according to new program. Ankara: Kök Publishing.

Arı, E., \& Demir, M. K. (2013). Assessing reading habits of student teachers' at department of elementary education. Journal of Mother Tongue Education, 1(1), 116-128.

Aslantürk, E. (2008). Comparison of elementary school teachers and prospective elementary teachers' reading interests and reading habits. (Unpublished master thesis). Adnan Menderes University Institute of Educational Sciences.

Aslantürk, E., \& Saracaloğlu, A. S. (2010). Comparison of elementary school teachers and prospective elementary teachers' reading interests and reading habits. Anadolu University Journal of Social Sciences, 11(1), 155-176.

Atak, M., Gündüz, E., Gür, Ü., Dikici, M., \& Yaman, Z. B. (2007). The knowledge, attitudes and behaviors of the teachers about reading reading working in the high school in the Kocasinan province of Kayseri. Paper presented at XVI. National Congress of Educational Sciences, 6-7 September, Gaziosmanpaşa University, Tokat.

Balc1, A. (2013). Reading and Comprehension Education. Ankara: Pegem Akademi Publishing.

Balc1, V. (2003). Investigating the Participation of University Students in Ankara to Leisure Activities. National Education, 158.

Batur, Z., Gülveren, H., \& Bek, H. (2010). A study about preservice teachers reading habits: sampling of usak education faculty. Uşak University Journal of Social Sciences, 3(1), 32-49.

Bozpolat, E. (2010). An assessment of prospective teachers' attitudes towards reading habit (case of cumhuriyet university education faculty). Journal of Worlf of Turks, 2(1), 411-428.

Demir, D. T. (2009). A survey on reading habits of prospective teachers for elementary school's second grade (case of gazi university). Turkish Studies, 4(3), 717-745. https://doi.org/10.7827/TurkishStudies.703

Dökmen, U. (1994). Psycho-social research on reading skills, interest and habit. İstanbul: MEB Publications.

Edizer, Z. Ç. (2014). Relationship between the attitudes of turkish prospective teachers on reading habits and their perceptions of the uses of metacognitive reading strategies. Kastamonu Education Journal, 23(2), 645-658.

Eğitim-Bir-Sen (2013). Teaching in turkey and in the world-rhetoric and practice. Ankara: Sistem Offset.

Eğitim-Bir-Sen (2016). View to education 2016-monitoring and evaluation report. Ankara: Semih Offset.

Esgin, A., \& Karadağ, Ö. (2000). Reading habits of university students. Popular Science, 19- 23.

Geçgel, H., \& Burgul, F. (2009). Interested reading area of education faculty studets (çanakkale case). Tübav Science Journal, 2(3), 341-353. 
Gömleksiz, M. N. (2004). Evaluation of your future teachers' views on reading: example of the faculty of education at firat university. Yüzüncü Yll University Electronic Journal of Education Faculty, 1(1), 1-21.

Gömleksiz, N. M., \& Telo, A. (2003). Reading habits of the students of the faculty of education (example of the faculty of education at firat university). Paper presented at I. Congress of Social Sciences Education, 15-17 May, Dokuz Eylül University.

Güneş, F. (2003). Importance of sentence in reading-writing teaching. Journal of Turkology Research, 13, 39-48.

İlyas, İ. E., Coşkun, İ., \& Toklucu, D. (2017). SETA Candidate teacher training model monitoring and evaluation report in Turkey. İstanbul: Turkuvaz Communication and Publishing.

Karadağ, R. (2014). Analysis of the graduate theses in the field of reading interest, attitudes and habits: the sample of yok and proquest database. Pamukkale University Journal of Education Faculty, 35, 1-17.

Karasar, N. (2000). Scientific research method. (10 ${ }^{\text {th }}$ Education). Ankara: Nobel Publishing.

Kırkkılıç, A., \& Maden, S. (2009). A constructivist model proposal for speed reading: speed reading and constructing the meaning. Turkish Studies, 4(3), 1423-1437.

Koçak, B., Çermik, F., Polat, S., \& Şahin, N. (2016). An evaluation about teacher candidates' reading attitude in terms of difference variable. International journal of Turkish Literature Culture Education, 5(1), 395-411. https://doi.org/10.7884/teke.588

Kolaç, E. (2007). Reader profiles of classroom teacher candidates. Paper presented at VI. National Symposium of Classroom Teacher Education, 27-29 April, Anadolu University, Eskişehir.

Konan, N. (2013). Reading habits of elementary school managers. Educational Administration: Theory and Practice, 19(1), 31-59.

Kuş, Z., \& Türkyılmaz, M. (2010). Reading statuses of social studies and turkish language teacher candidates (their attention, habits and levels of using reading strategies). The Journal of Turkish Librarianship, 24(1), 11-32.

LaBonty, J. (1991). College students as readers. Reading Horizons, 32(1), 21-32.

Manguel, A. (1997). A history of reading. London:Penguin Books.

McNinch, G. W., \& Steelman, P. (1990). Perceived reading status of teacher education students. Reading Improvement, 27(3), 203-206.

Myers, A. (1983). Reading in the problem years: some strategies. The School Librarian, 31(4), 328-331.

Odabaş, H, Odabaş, Z. Y., \& Coşkun, P. (2008). Reading habit of university students: the model of ankara university. Information World, 9(2), 431-465.

Olson, M. W., \& Gillis, M. (1983). Teaching reading study skills and course content to preservice teachers. Reading World, 23(2), 124-133. https://doi.org/10.1080/19388078309557752

Orhan, S., Arslan, A., \& Akçay, A. (2011). Evaluation of Turkish language and literature teachers' attitudes towards reading habits according to various variables. Paper presented at International Symposium of Turkish Education, 15-17 December, Gazi University, Ankara.

Özbay, M., Bağc1, H., \& Uyar, Y. (2008). evaluation of the preservice Turkish teachers' attitudes towards reading habit according to some variables. İn̈̈n̈̈ University Journal of Education Faculty, 9(15), 117-136.

Özçelebi, O. S., \& Cebecioğlu, N. S. (1990). Reading habit and turkey. İstanbul: Milliyet.

Sağlam, M., Suna, Ç., \& Çengelci, T. (2007). Comparison of Levels of Reading and Writing in Elementary Teachers and Other Teaching Programs Students. Paper presented at VI. National Symposium Classroom Teaching, 27-29 April, Anadolu Üniversitesi, Eskişehir.

Sağlamtunç, T. (1990). A study on the free (empty) time-out-of-school reading habits of 4th grade students in university librarianship departments in Turkey. The Journal of Turkish Librarianship, 4(1), 3-21.

Şahin, A. (2009). A study on primary education 6th 7th and 8th grade students reading habits according to their socio-economic status. Mersin University Journal of Education Faculty, 5(2), 215-232.

Şahiner, Y. (2005). Reading habits of primary school teachers and factors affecting their reading habits. (Unpublished master thesis). Ankara University Institute of Educational Sciences.

Saracaloğlu, A. S., Bozkurt, N., \& Serin, O. (2003). Factors affecting reading interest and reading habit of university teacher. Eurasian Journal of Educational Research 4(12), 149-157. 
Saracaloğlu, A. S., Karasakaloğlu, N., \& Yenice, N. (2007). The relationship between problem-solving skills of teacher candidates and reading interests and habits. Paper presented at VI. National Symposium Classroom Teaching, 2729 April, Anadolu Üniversitesi, Eskişehir.

Sarıhan, Z. (2003). An incomplete project to read books for students: a book every month on schools. Journal of Education for Life, 31-34.

Semerci, Ç. (2002). The reading habits of the students of physical education and sport departments in turkish universities. Education and Science, 27(125), 36-43.

Sönmez, V. (1989). The economic situation of the teacher in Turkey. Hacettepe University Journal of Education Faculty, 4, 77-84.

Soysal, Ö. (1989). On literacy and reading habit. The Journal of Turkish Librarianship, 3(1): 46-51.

Süngü, H. (2012). A comparative analysis of teachers' salaries in some oecd countries. Education and Society in the $21^{s t}$ Century, 1(2), 21-45.

Timbs, L. C. (1993). From couch potatoes to readers: enriching undergraduate education. Journalism Educator, 48, 81-83. https://doi.org/10.1177/107769589304800209

Tunçkaşı, H. (2007). Teacher salaries in Turkey and in various countries. Ankara: Research Center of The Grand National Assembly of Turkey.

Türk Eğitim Sen (2011). Survey of teachers' socio-economic situation. Ankara: Türk Eğitim Sen Publishers.

Ungan, S. (2008). The cultural background of our reading habit. Gaziantep University Journal of Social Sciences, $7(1): 218-228$.

Yağcı, Y. (2007). Bridges for children and young people reaching the book. The Journal of Turkish Librarianship, 21(1), $62-71$.

Yalçın, A. (2006). Turkish teaching methods new approaches. Ankara: Akçağ Publishing.

Yalman, M., Özkan, E., \& Başaran, B. (2015). Future teachers' investigation of reading habits: example of dicle university. EKEV Academy Journal, 19(61), 463-478.

Yıldırım, N. (2013). A qualitative study on 100 books proposal for educators. International Journal of Turkish Education Sciences, 1(1), 106-118.

Y1lmaz, B. (2002). A research on reading and public library use habits of the primary school teachers in ankara. The Journal of Turkish Librarianship, 16(4), 441-460.

Yilmaz, B. (2004a). Sensitivities of the parents on the reading and library use habits of the students. Information World, $5(2), 115-136$.

Y1lmaz, B. (2004b). Reading habit and teacher. Presented at Meeting of Reading Culture and Implemantations Problems at Schools. Ankara: Ministry of National Education, 133-142.

Yılmaz, Z. A. (2006). The reading habit of elementary school teacher candidates. Elemantary Education Online, 5(1), $1-6$.

\section{Copyrights}

Copyright for this article is retained by the author(s), with first publication rights granted to the journal.

This is an open-access article distributed under the terms and conditions of the Creative Commons Attribution license which permits unrestricted use, distribution, and reproduction in any medium, provided the original work is properly cited. 